\title{
Modern sedimentation and geochemical imprints in sediments from the NW Madagascar margin
}

\author{
Pastor Lucie ${ }^{1,}{ }^{*}$, Brandily Christophe ${ }^{1}$, Schmidt S. ${ }^{2}$, Miramontes E. ${ }^{3}$, Péron Maela ${ }^{1}$, Appere Dennis ${ }^{1}$, \\ Chéron Sandrine ${ }^{4}$, Boissier Audrey ${ }^{4}$, Jouet Gwenael 5
}

1 IFREMER, Centre de Bretagne, REM/EEP, Laboratoire Environnement Profond, F-29280 Plouzané, France

2 UMR5805 EPOC, CNRS, OASU, Université de Bordeaux, 33615 Pessac, France

${ }_{3}^{3}$ MARUM - Center for Marine and Environmental Sciences, University of Bremen, Klagenfurter Straße 2-4, Bremen 28359, Germany

${ }^{4}$ IFREMER, Centre de Bretagne, REM/GM, Laboratoire Cycles Géochimiques et Ressources, F-29280

Plouzané, France

${ }^{5}$ IFREMER, Centre de Bretagne, REM/GM, Laboratoire Géodynamique et Enregistrement

Sédimentaire, F-29280 Plouzané, France

* Corresponding author : Lucie Pastor, email address : lucie.pastor@ifremer.fr

\begin{abstract}
:
The NW Madagascar continental margin receives high loads of terrigenous particulate organic matter during the wet season and especially linked to extreme events, originating from two major rivers, the Betsiboka and the Mahavavy Rivers. This particulate matter contains a high content of iron minerals from the weathering of red ferruginous/ferralitic soils of Madagascar. The presence of pockmarks, i.e. gas or fluid expulsion features on the continental slope, testifies to past/present methane migration through the sedimentary column, associated with early diagenetic processes. This study globally aims at deciphering the interactions between episodic sedimentation and geochemical processes influenced by fluids upward migration, using a sediment trap mooring and interface sediment cores at two sites on the continental slope. The present-day sedimentation along this margin undergoes two patterns. During the wet season, high continental fluxes generally result in an increase in particle fluxes on the slope. Longshore currents may deflect river plumes alongslope resulting in some periods of low particle flux on the slope during the wet season. During the dry season, the particles collected in the water column are probably originated from sediment remobilization from the shelf and slope. The observed progradation of the Mahavavy River delta and prodelta between 1984 and 2016 argues for an increase in temporary connections of the river with the canyon head during extreme events, inducing pulsed sedimentation offshore. This pulsed sedimentation could be responsible for enhancing pyritization on surface sediments, due to higher inputs of terrigenous organic matter and iron oxides. Finally, methane upward migration also influences the pyritization process through anaerobic oxidation of methane using sulfate as an electron acceptor and methanotrophs associated with this reaction significantly impact the $\delta 13 \mathrm{C}$ of organic carbon towards more negative values.
\end{abstract}




\section{Highlights}

- The NW continental slope of Madagascar presents moderate sediment accumulation rates, with sediment transport mainly during the wet season - Recent episodic sedimentation events are due to temporary reconnection of the Mahavavy River with its canyon head during extreme events episodic events carry sediment rich in organic carbon and iron oxides, which influence geochemical processes in the sedimentary column - The large inputs of iron oxides in this area enhance pyritization efficiency Past and present methane outputs influence geochemical signatures in the sediment (sulfur minerals and $\delta^{13} \mathrm{C}$ of bulk organic carbon)

Keywords : Episodic sedimentation, Madagascar margin, Betsiboka rive, $r$ Mahavavy river, Progradation, Methane escapement, Geochemistry Sediment 


\section{INTRODUCTION}

Rivers represent the largest transportation pathway of organic particulate matter to coastal areas, and subsequently to continental shelves, slopes and deep ocean basins (Bauer et al., 2013). Continental margins, which encompass the continental shelf, slope and rise, are thus impacted by high inputs of terrigenous organic material, $55-80 \%$ of this flux being remineralized in the upper sedimentary column along these margins (Burdige, 2005). The remainder could undergo long term biogeochemical reactions like oil and gas formation at depth that could eventually migrate through the sedimentary column, or be finally buried. Geochemical signatures in margin sediments are thus influenced by several factors, including sedimentation intensity and nature, episodic events and diagenetic processes. Diagenetic processes can modify, for instance, the $\delta^{13} \mathrm{C}$ signature of organic matter through its mineralisation ( $M^{c}$ arthur et al., 1992), the isotopic composition of several elements in foraminifera tests through the dissolution/reprecipitation of carbonates phases (Edgar et al., 2015), or the magnetic properties of sediment through the dissolution and precipitation of iron phases (Larrasoana et al., 2009). In environments where diagenetic processes are highly diverse like in cold seeps areas or deltaic environments, it can be intricate to quantify their relative impact on 
paleosignatures. Thus, studies aiming at reconstructing paleosignals or determining the source of sediments have to take early diagenesis into account.

The NW continental margin of Madagascar receives large amount of sediment from two main rivers, the Betsiboka and the Mahavavy Rivers. There are also evidences of local methane escapes on the continental slope (Acoustic anomalies detected in the water column - Dupré et al., 2019). The sediment dynamics and geochemical signatures on the continental slope under the influence of the rivers input have been monitored using one mooring with a sediment trap, temperature and current velocity measurements, and interface sediment cores. The objectives of this work were to 1) give a first insight on the modern sedimentary patterns along this slope and 2) decipher the relative impact of the sedimentation versus methane escape on geochemical signatures $\left(\mathrm{Ti} / \mathrm{Ca}, \mathrm{Ti} / \mathrm{Al}, \mathrm{\delta}^{13} \mathrm{C}\right.$ of organic matter, sedimentary sulfur and iron) of sediment, in order to distinguish between changes in inputs versus changes in diagenetic processes.

\section{REGIONAL SETTING}

The Majunga basin is one of the two major sedimentary basins of Madagascar (with the Morondava basin). This basin partly covers onshore and offshore areas (Tari et al., 2004). In this paper, we only discuss data from the offshore Majunga basin. The Betsiboka River is the largest river in Madagascar with a length of $605 \mathrm{~km}$ and a watershed of $49,000 \mathrm{~km}^{2}$ (Randrianarijaona, 1983). Spectacular gullies, named lavakas by the Malagasy people, are widespread in Madagascar and are especially dense in the highlands of central Madagascar around the Betsiboka watershed (Cox et al., 2010). The river supplies the coastal area with sediment eroded from ferruginous and ferralitic soils of the Majunga basin and of the lavakas (Ramifehiarivo et al., 2017). Fluvial discharges varies from $35 \mathrm{~m}^{3} \mathrm{~s}^{-1}$ during a very dry season to $4,500 \mathrm{~m}^{3} \mathrm{~s}^{-1}$ during wet periods, with extreme values during flood reaching > 25,000 $\mathrm{m}^{3} \mathrm{~s}^{-1}$ (Berthois and Crosnier, 1966; Chaperon et al., 1993). From measurements in surface waters, solid transport was estimated in the $1960 \mathrm{~s}$ at about $1660 \mathrm{t} \mathrm{yr}^{-1}$, which corresponds to $1.1 \mathrm{~mm}$ 
of soil eroded per year for the whole watershed (Chaperon et al., 1993). During flood events, the plume of fine suspended particles reaches up to $17 \mathrm{~km}$ offshore towards the north and about $13 \mathrm{~km}$ in the east-west direction alongshore (Berthois and Crosnier, 1966). Otherwise, particles remain confined within the estuary (coarse material) and within a few kilometers north of the outlet on the shelf (fine particles).

About $50 \mathrm{~km}$ westward, the Mahavavy River is $410 \mathrm{~km}$ long and has a watershed of $18,500 \mathrm{~km}^{2}$. Its connection to the ocean forms a long delta spread along approximately $20 \mathrm{~km}$ of coastline. Discharge was measured randomly at Marovato between 1950 and 1973 with a range of $26-4,300 \mathrm{~m}^{3} \mathrm{~s}^{-1}$ (Chaperon et al. 1993). There is currently no estimate for solid transport.

There are no recent hydrogeological data for these two rivers. Both river outlets are located on the northern tip of Madagascar that has been uplifting at a rate of $0.02-0.08 \mathrm{~mm} \mathrm{yr}^{-1}$ over the last $0.1-$ 0.8 Ma (Battistini, 1972; Roberts et al., 2012). Accretion and mangrove colonization on new-formed mudflats have been evidenced (Salomon, 2009). Continuous deforestation on the island since 1600 $A D$ coupled with a growing population relying on agriculture (Harper et al., 2007; Klein, 2002) contributes to the very high erosion rates, between 250 and $400 \mathrm{t} \mathrm{ha}^{-1} \mathrm{yr}^{-1}$, in the highlands, among the highest rates measured worldwide (Randrianarijaona, 1983).

The circulation in the Comoros Basin and the NW margin of Madagascar is characterized by intense mesoscale eddies that result in a high variability in the direction and intensity of oceanic currents (Collins et al., 2014; 2016; Pripp et al., 2014). Anticyclonic eddies are mainly generated west of Cape Amber (northernmost tip of Madagascar) and are associated with the North East Madagascar Current (NEMC), while cyclonic eddies are mainly formed along the northwestern margin of Madagascar due to strong baroclinic instability (Collins et al., 2014). The NW Madagascar margin is very often affected by cyclonic eddies that generate currents flowing SW along the slope that can 
deflect the river plumes and affect sediment transfer from the continent to the deep sea (Figure 1C; Collins et al., 2016; Pripp et al., 2014).

\section{MATERIEL AND METHODS}

\subsection{Sampling strategy}

The North western Madagascar margin in the Comoros Basin was investigated during two cruises: the PAMELA-MOZ1 cruise in 2014 (Olu, 2014) aboard the RV L'Atalante and the PAMELA-MOZ4 cruise in 2015 (Jouet and Deville, 2015) aboard the RV Pourquoi pas?. The two main sampling sites are located on the upper continental slope, offshore the outer shelf carbonate reefs where water depths increase from a few meters to a few hundred meters. This area is characterized by a number of pockmarks (i.e. sedimentary depressions formed during gas or fluid expulsion) located between 400 and $750 \mathrm{~m}$ depth (Figure 1).

Site S1 is located $30 \mathrm{~km}$ off the Mahavavy River at a water depth of $789 \mathrm{~m}$ (Figure 1 - Table 1). At this site, a mooring (MLP1), equipped with a current-meter and a sediment trap, was deployed in October 2014 and retrieved in November 2015. It was positioned at a water depth of $781 \mathrm{~m}$ (Figure 1 -Table1). It was equipped with a RCM 11 current meter (Aanderra) positioned $30 \mathrm{~m}$ above the bottom (mab) and coupled to a sediment trap (PPS 4/3, 24 sampling bottles), with a sampling surface of $1 \mathrm{~m}^{2}$, positioned 10 mab. Additionally, two multicorers were deployed within a pockmark (diameter $=600 \mathrm{~m})$ in $2014(\mathrm{~S} 1-\mathrm{P}$ - Table 1 - Figure 1). Site S2 is located $\sim 30 \mathrm{~km}$ north-eastwards of site 1, $50 \mathrm{~km}$ off the Betsiboka River estuary, at a water depth ranging from 529 to $762 \mathrm{~m}$ (Figure 1 Table 1). At this site, one pockmark was sampled through multicores taken inside (diameter $=220 \mathrm{~m}$, S2-P1 in 2014 and S2-P2 in 2015 - Figure 1) and outside the same pockmark around its edge (S2-PE1 in 2014 and S2-PE2 in 2015 - Figure 1). Two additional multicores were collected, one outside the pockmarks area in 2014 (S2-OUT - Figure 1) and one in 2015 on a slope where gas seeping was 
evidenced using water column acoustic data (Dupré et al., 2019) (S2-G - Figure 1). Salinity was measured in the water column using a SEACAT SBE19 CTD.

\subsection{Samples treatment}

Before deployment of the mooring, sampling bottles were filled with filtered seawater and sodium borate-buffered formalin to a final concentration of $3 \%$. Settling particles were collected from 26 October 2014 to 15 November 2015 with a constant sampling interval of 17 days. Samples were kept at $4^{\circ} \mathrm{C}$ before treatment. In the laboratory, the content of each bottle was visually examined to retrieve swimmers, identified as organisms larger than $1 \mathrm{~mm}$, and rinsed with Milli-Q water to remove salts and formalin. Particles were freeze-dried, weighed to determine mass flux, and crushed for further geochemical analysis.

Interface sediments were collected with a multicorer equipped with eight Plexiglas tubes $(96 \mathrm{~mm}$ internal diameter). Twenty to forty centimetres of undisturbed sediment cores were retrieved with their overlying water. Photographs were taken of the half section of one core. One core was sliced horizontally every $0.5 \mathrm{~cm}$ from the sediment-water interface to $2 \mathrm{~cm}$ depth, every $1 \mathrm{~cm}$ to $10 \mathrm{~cm}$ depth and then every $2 \mathrm{~cm}$ downcore. Each layer was immediately frozen $\left(-80^{\circ} \mathrm{C}\right)$ on board in a preweighed vial. Back at the laboratory, sediment was weighed, freeze-dried, weighed again and then homogeneously crushed into a fine powder. Porosity was calculated considering the wet and freezedried weight and assuming a sediment bulk density of $2.7 \mathrm{~g} \mathrm{~cm}^{-3}$ (standard value for mud - (Hamilton, 1976)). It was corrected for salt content using measured bottom water salinity. A second core was used to sample porewater using rhizons ${ }^{\circledR}$ (Rhizosphere Research Products) usually every 1 or $2 \mathrm{~cm}$. One aliquot (2-4 mL) was stored in a $10 \mathrm{~mL}$ glass vial with $15 \mu \mathrm{l}$ of $\mathrm{HgCl}_{2}$, and sealed for further methane measurements. As rhizons are not adequate to measure gas concentration, one core S2-G was sub-sampled during its extrusion; $3 \mathrm{cc}$ of sediment were immediately collected in each layer 
using a pre-cut syringe, directly transferred into a $20 \mathrm{~mL}$ glass vial with $5 \mathrm{~mL} 1 \mathrm{M} \mathrm{NaOH}$, sealed and stored head-down at $4^{\circ} \mathrm{C}$ before methane measurement at the laboratory.

\subsection{Analyses}

Total sulfur and carbon were determined using a Leco CNS-2000 auto-analyzer. The organic carbon content (OC) was measured with a Leco CS-125 elemental analyzer after removing carbonates overnight at a temperature of $60^{\circ} \mathrm{C}$ with $30 \% \mathrm{HNO}_{3}$. Inorganic carbon (IC) was calculated from the difference between total and organic carbon.

Crystalline oxi-hydroxides of iron and manganese were determined by dithionite extractions $\left(\mathrm{Mn}_{\text {dith }}\right.$ and $\mathrm{Fe}_{\mathrm{dith}}$ ) (Kostka and Luther III, 1994) coupled to ICP-AES determination using a Horiba Jobin Yvon ${ }^{\circledR}$ Ultima 2 spectrometer. A certified sediment (MESS-4, NRC-CNRC) was used to check the repeatability of the extractions through time. The global variability of MESS-4 was around 5\% (standard error).

$\delta^{13} \mathrm{C}$ of the sedimentary organic matter was determined using Combustion Module-Cavity Ring Down Spectroscopy (CM-CRDS - Picarro) (Balslev-Clausen et al., 2013). Around $250 \mathrm{mg}$ of samples were first acidified with successive additions of $\mathrm{HCl} 1 \mathrm{~N}$ at $40^{\circ} \mathrm{C}$ until complete carbonate dissolution and rinsed twice with milli- $\mathrm{Q}$ water to retrieve acid. After freeze-drying, around $10 \mathrm{mg}$ were then introduced into $5 \times 9 \mathrm{~mm}$ tin capsules for analysis. Calibration was performed using International Atomic Energy Agency (IAEA) reference material: calcite (NBS-18), sucrose (CH-6) and lithium carbonate (LSVEC). An acetalinide standard (Costech) was inserted every ten samples to correct for the drift, with a measured value of $-33.50 \pm 0.02 \%$ ( 6 replicates). Precision was typically within 0.03 $\%$ for a triplicate.

${ }^{210} \mathrm{~Pb}$ and ${ }^{226} \mathrm{Ra}$ were measured on dried particles and sediments using a high-efficiency, lowbackground well-type germanium detector (Canberra) (Schmidt et al., 2009). The standard used for the calibration of the gamma spectrometer is IAEA RGU-1. Excess ${ }^{210} \mathrm{~Pb}$ in settling particles and in sediments, ${ }^{210} \mathrm{~Pb}_{\mathrm{xs}}$, was calculated by subtracting the activity supported by its parent isotope, ${ }^{226} \mathrm{Ra}$, 
from the total measured ${ }^{210} \mathrm{~Pb}$ activity. Errors on ${ }^{210} \mathrm{~Pb}_{\mathrm{xs}}$ were calculated by propagating the errors on ${ }^{210} \mathrm{~Pb}$ and ${ }^{226} \mathrm{Ra}$ measurements. Sediment accumulation rate (SAR, expressed in $\mathrm{cm} \mathrm{yr}^{-1}$ ) was calculated from the decrease of ${ }^{210} \mathrm{~Pb}_{\mathrm{xs}}$ with depth using the CFCS (constant flux and constant sediment model (Schmidt et al, 2009)). The mass accumulation rate (MAR, expressed in $\mathrm{g} \mathrm{m}^{-2} \mathrm{~cm}^{-1}$ ) is obtained by plotting the regression of ${ }^{210} \mathrm{~Pb}_{\mathrm{xs}}$ against cumulative mass.

The bulk sediment semi-quantitative geochemical composition was measured with an Avaatech X-ray fluorescence (XRF) core scanner on half sections. Measurements were carried out every one millimeter applying a basic voltage of 10 and $30 \mathrm{kV}$ to estimate elemental relative concentrations (aluminum (Al), sulfur (S), calcium (Ca) and titanium (Ti)). Results are given in counts per second (Cps).

Quantitative X-ray Fluorescence (XRF) analyses were carried out on selected samples from S1-ST in order to obtain the elemental composition (e.g. $\mathrm{TiO}_{2}, \mathrm{CaO}, \mathrm{Al}_{2} \mathrm{O} 3, \mathrm{Fe}_{2} \mathrm{O}_{3}$ ). Half a gram of dried sediment was fused at $1050^{\circ} \mathrm{C}$ with $9 \mathrm{~g}$ of fusion flux $\left(90 \%\right.$ lithium tetraborate $\left(\mathrm{LiB}_{4} \mathrm{O}_{7}\right) / 10 \%$ of lithium fluoride (LiF)) and $500 \mu \mathrm{L}$ of lithium bromide solution ( $\mathrm{LiBr}$ ) at $250 \mathrm{~g} \mathrm{~L}^{-1}$. The obtained fused beads were analyzed on a sequential X-ray wavelength dispersive spectrometer (WD-XRF) with a Rh X-ray tube (S8 Tiger from Bruker). A set of certified geostandards from the "Canadian Certified reference materials Project" (CCRMP - FER-1, FER-2, WMG-1), the "Geological Survey of Japan" (GSJ JB-3, JCFA-1, JLs-1, JSD-2) and the "Centre de Recherches Pétrochimiques et Géochimiques" in France (CRPG - BE-N, IF-G) was used for the calibration. All samples were analyzed twice, with a third run in case of divergence. The relative error on major elements (up to $1 \%$ ) is below $5 \%$. Variations in Ti/Ca and Ti/Al ratios calculated from semi-quantitative XRF throughout the cores are used to point depositional events, while molar ratios calculated from quantitative XRF on S1-ST are used to check variations during the sampling time. 
Methane concentrations were measured by headspace gas chromatography with a PR2100 gas chromatograph equipped with a flame ionization detector (GC/FID Perichrom, France) connected to a headspace injector (dani HSS 86.50)(Sarradin and Caprais, 1996).

\section{RESULTS}

All geochemical data are provided in supplementary material.

\subsection{Currents and particulate fluxes in site 1}

Current velocities measured $30 \mathrm{~m}$ above the seafloor reached up to $42 \mathrm{~cm} \mathrm{~s}^{-1}$ with an averaged value of $7.8 \mathrm{~cm} \mathrm{~s}^{-1}$ (FIGURE CAPTIONS

Figure 1: (A) The NW Madagascar margin and the Mahavavy and Betsiboka watersheds. The two main sites (S1, S2) are indicated by a star. (B) Detailed bathymetry of the sampled area and location of the sampling sites (C) Satellite image (MODIS/Aqua corrected reflectance) of 16 March 2015, obtained from the NASA Worldview application, showing how river plumes are deflected towards the north by alongshore currents and sediment in suspension is carried from the northern part towards the south by longshore currents.

Figure 2: (A) Temperature and speed time series at $30 \mathrm{~m}$ above the seafloor at S1. The light blue curves represent the raw data and the dark blue lines averaged values every $12 \mathrm{~h}$. (B) Rose diagram of current direction and speed at $30 \mathrm{~m}$ above the seafloor at S1.

Figure 3: Spectra of kinetic energy based current velocity (A) and temperature (B) at S1 (blue line) and 98\% confidence level (red lines). M2 is the semi-diurnal tide (12.42 h) and M4 is the quatridiurnal tidal constituent (6.21 h).

). Daily means ranged between 4.3 and $15.5 \mathrm{~cm} \mathrm{~s}^{-1}$. Main current directions were N-NNE and S-SSW (Figure 2B). These changes in current direction are related to tides (Figure 3A). Temperature ranged between 6.5 and $9.4^{\circ} \mathrm{C}$ with an averaged value of $7.8^{\circ} \mathrm{C}$ (FIGURE CAPTIONS

Figure 1: (A) The NW Madagascar margin and the Mahavavy and Betsiboka watersheds. The two main sites (S1, S2) are indicated by a star. (B) Detailed bathymetry of the sampled area and location of the sampling sites (C) Satellite image (MODIS/Aqua corrected reflectance) of 16 March 2015, obtained from the NASA Worldview application, showing how river 
plumes are deflected towards the north by alongshore currents and sediment in suspension is carried from the northern part towards the south by longshore currents.

Figure 2: (A) Temperature and speed time series at $30 \mathrm{~m}$ above the seafloor at S1. The light blue curves represent the raw data and the dark blue lines averaged values every $12 \mathrm{~h}$. (B) Rose diagram of current direction and speed at $30 \mathrm{~m}$ above the seafloor at S1.

Figure 3: Spectra of kinetic energy based current velocity (A) and temperature (B) at S1 (blue line) and 98\% confidence level (red lines). M2 is the semi-diurnal tide (12.42 h) and M4 is the quatridiurnal tidal constituent (6.21 h).

A). A slight decrease in temperature from 8.0 to $7.7^{\circ} \mathrm{C}$ on average is also visible from mid-February to September (FIGURE CAPTIONS

Figure 1: (A) The NW Madagascar margin and the Mahavavy and Betsiboka watersheds. The two main sites (S1, S2) are indicated by a star. (B) Detailed bathymetry of the sampled area and location of the sampling sites (C) Satellite image (MODIS/Aqua corrected reflectance) of 16 March 2015, obtained from the NASA Worldview application, showing how river plumes are deflected towards the north by alongshore currents and sediment in suspension is carried from the northern part towards the south by longshore currents.

Figure 2: (A) Temperature and speed time series at $30 \mathrm{~m}$ above the seafloor at S1. The light blue curves represent the raw data and the dark blue lines averaged values every $12 \mathrm{~h}$. (B) Rose diagram of current direction and speed at $30 \mathrm{~m}$ above the seafloor at S1.

Figure 3: Spectra of kinetic energy based current velocity (A) and temperature (B) at S1 (blue line) and 98\% confidence level (red lines). M2 is the semi-diurnal tide (12.42 h) and M4 is the quatridiurnal tidal constituent (6.21 h).

A). A tropical storm (Chedza) occurred on 16 January 2015, but no significant changes in current nor temperature were observed associated with this event (Figure 2). Temperature shows highfrequency oscillations related to tides (Figure 3B).

The cumulated rainfall recorded in Majunga, at the Betsiboka outlet, indicates that the wet season spread from November to March/April, with a daily maximum of $59.8 \mathrm{~mm}$ the January $11^{\text {th }}$ (www.worldweatheronline.com/majunga-weather-history/mahajanga/mg.aspx). During the 13 days preceding the tropical storm Chedza, total rain of $361 \mathrm{~mm}$ was recorded in Majunga. The total 
sediment mass flux (TMF) recorded in the sediment trap varied between 0 (from February 22nd to March 11th) and $2837 \mathrm{mg} \mathrm{m}^{-2} \mathrm{~d}^{-1}$ (from January 2nd-19th), this maximum being recorded around the Chedza storm (Figure 4). From January 2 nd to February 5th, we suspect that particles have overflowed the sampling bottles, which may lead to an underestimation of the bi-weekly TMF during this period, as part of the particles may have been stored in the next one or two bottle(s). Then, even if the absolute bi-weekly TMF from January 2 nd to February 22nd should be taken with caution, the cumulated TMF remains correct. TMF varied between 51 and $750 \mathrm{mg} \mathrm{m}^{-2} \mathrm{~d}^{-1}$ during the dry season. During the wet season, the daily averaged particulate mass export was multiplied by 2.8 compared to the dry season (353 versus $124 \mathrm{~g} \mathrm{~m}^{-2} \mathrm{~d}^{-1}$ ). Organic and inorganic carbon contents ranged between $1.9 \%$ and $3.0 \%$, and $1.8 \%$ and $2.8 \%$, with averaged values of $2.3 \%$ and $2.2 \%$, respectively, without drastic evolution (Figure ). Total sulfur (Figure 4) varied from $0.16 \%$ to $0.51 \%$ (average $0.37 \%$ ), with higher values during the dry season. $\delta^{13} \mathrm{C}$ of organic carbon varied from -21.6 to $-20.6 \%$ (average $21.0 \%$ o) (Figure 4). ${ }^{210} \mathrm{~Pb}_{\mathrm{xs}}$ activities present also a limited variability, between 1794 and $2256 \mathrm{mBq}$ g-

${ }^{1}$, the lowest levels correspond to the lowest mass fluxes. $\mathrm{Mn}_{\text {dith }}$ ranged between $3.5 \mu \mathrm{mol} \mathrm{g}^{-1}$ during the dry season up to $12.9 \mu \mathrm{mol} \mathrm{g} \mathrm{g}^{-1}$ during the wet season, with a marked increase of concentration during the wet season. $\mathrm{Fe}_{\text {dith }}$ ranged between 488 and $527 \mu \mathrm{mol} \mathrm{g}^{-1}$ with no clear pattern during the year. $\mathrm{TiO}_{2}, \mathrm{CaO}, \mathrm{Al}_{2} \mathrm{O}_{3}$ and $\mathrm{Fe}_{2} \mathrm{O}_{3}$ ranged between $0.62-0.71 \%, 8.1-12.1 \%, 17.0-18.4 \%, 6.4-7.1 \%$, respectively, through the sampling period. $\mathrm{Ti} / \mathrm{Ca}$ and $\mathrm{Ti} / \mathrm{Al}$ ratios ranged between $0.040-0.054$ and 0.023-0.026, respectively, with no significant variations.

\subsection{Sediments characteristics}

\subsubsection{Visual description of the cores}

The image of S1-P highlights marked layers of sediments of different colors $(0-16 \mathrm{~cm})$, from orange at the top, followed by a well-defined black layer, a brownish/dark orange layer, some diffuse black sediment and dark grey sediment at depth (Figure 5). S2-P1 and S2-P2 were taken at the same surface GPS point during MOZ1 (2014) and MOZ4 (2015) cruises, respectively, and look very different 
(Figure 6). S2-P1 exhibits an orange layer at the top $(0-10 \mathrm{~cm})$ with traces of bioturbation, followed by light greenish sediment. S2-P2 is much darker with a black layer at the top (0-6 cm). S2-PE1 and S2-PE2 were taken at the same surface GPS point during MOZ1 (2014) and MOZ4 (2015) cruises, respectively, and both exhibit an orange layer at the top (thicker in S2-PE2) and a light greenish sediment underneath (Figure 6). S2-G is dark gray all along the core. Finally, S2-OUT has a thick orange layer at the top $(0-20 \mathrm{~cm})$ followed by light greenish sediment (Figure 6).

\subsubsection{Sediment and mass accumulation rates}

${ }^{210} \mathrm{~Pb}_{\mathrm{xs}}$ profiles were determined on 3 cores at site 2 (S2-PE1; S2-PE2; S2-G - Figure 6). ${ }^{210} \mathrm{~Pb}_{\mathrm{xs}}$ activities are rather comparable in the top sediment, ranging between 548 and $845 \mathrm{mBq} \mathrm{g}^{-1}$, and present an exponential decrease with depth to reach negligible level at about $10 \mathrm{~cm}$. The limited variability in sedimentation rates among the different cores at site 2 , regardless of their position, results in very similar ${ }^{210} \mathrm{~Pb}_{\mathrm{xs}}$ profiles and thus similar SAR and MAR. At the edge of a pockmark (S2-PE1 and S2-PE2), the SAR is $0.052 \pm 0.004 \mathrm{~cm} \mathrm{yr}^{-1}$ and $0.039 \pm 0.005 \mathrm{~cm} \mathrm{yr}^{-1}$ while the MAR is $249 \mathrm{~g} \mathrm{~m}^{-2} \mathrm{yr}^{-1}$ and $230 \mathrm{~g} \mathrm{~m}^{-}$ ${ }^{2} \mathrm{yr}^{-1}$, respectively. On a gas escape at S2-G, the SAR is $0.059 \pm 0.006 \mathrm{~cm} \mathrm{yr}^{-1}$ and the MAR is $243 \mathrm{~g} \mathrm{~m}^{-2}$ $\mathrm{yr}^{-1}$. In fact, the mass accumulation rate, which integrates the compaction effect, is equivalent at the three sites, indicating a rather homogenous particle deposition on the area. The profile of ${ }^{210} \mathrm{~Pb}_{\mathrm{xs}}$ is completely different at site 1 (Figure 5): first, the top ${ }^{210} \mathrm{~Pb}_{\mathrm{xs}}$ activity is much higher compared to S2 cores $\left(1372 \mathrm{mBq} \mathrm{g}^{-1}\right)$, and is closer to the activities recorded in the sediment trap. In addition, the ${ }^{210} \mathrm{~Pb}_{\mathrm{xs}}$ profile in core $\mathrm{S} 1-\mathrm{P}$ presents a decrease according to two slopes, which is interpreted as a change in sedimentation intensity. In the most recently deposited sediments, from the top to about $16 \mathrm{~cm}$, the SAR is $0.249 \pm 0.054 \mathrm{~cm} \mathrm{yr}^{-1}$ (Figure 5), which corresponds to a mean MAR of $1381 \mathrm{~g} \mathrm{~m}^{-2} \mathrm{yr}^{-}$ ${ }^{1}$ (Fontanier et al., 2018). Deeper in the sediment (> $16 \mathrm{~cm}$; before 1950s), the SAR is much lower $(0.057 \pm 0.007) \mathrm{cm} \mathrm{yr}^{-1}$ (Figure 5), which corresponds to a MAR of $320 \mathrm{~g} \mathrm{~m}^{-2} \mathrm{yr}^{-1}$. In addition to the main pattern, ${ }^{210} \mathrm{~Pb}_{\mathrm{xs}}$ activities present low activities at 2-3, 13-14 and $19 \mathrm{~cm}$ (Figure 5), that could be the result of a temporary input of $l o w{ }^{210} \mathrm{~Pb}_{\mathrm{xs}}$ particles. 


\subsubsection{Geochemical data}

Sedimentary OC concentrations ranged between $0.8 \%$ and $2.4 \%$ (Figures 5 and 6 ), IC concentrations between $0.3 \%$ and $5.7 \%$, and total S between $0.07 \%$ and $3.7 \%$. S1-P recorded the highest values of $\mathrm{OC}$ and $\mathrm{S}$, and the lowest values of IC. In all cores, $\mathrm{Mn}_{\text {dith }}$ ranged between 0.5 and $17.9 \mu \mathrm{mol} \mathrm{g}{ }^{-1}$ and $\mathrm{Fe}_{\text {dith }}$ between 95.7 and $710.8 \mu \mathrm{mol} \mathrm{g}^{-1}$.

Ca values measured by semi-quantitative usually ranged between $1.10^{5}$ and $2.10^{5} \mathrm{Cps}$, with lower values at the top of cores from sites S2-P2, S2-G and S1-P. S values measured by semi-quantitative XRF are usually $<2000 \mathrm{Cps}$, with higher values in S2-P2, S2-G and S1-P (up to $7500 \mathrm{Cps}^{\mathrm{s}-1}$ ). Ti/Ca are in average around $0.04-0.06$, with high variations at the top of S2-P2, S2-G and S1-P. Ti/Al ranged between 2 and 5 in all sites.

A ternary plot between $\mathrm{OC}, \mathrm{S}$ and $\mathrm{Fe}_{\text {dith }}$ separate 2 distinct groups of sites (Figure 7): the first group with a higher relative proportion of total $\mathrm{S}$ and lower $\mathrm{Fe}_{\text {dith }}$ contribution (S2-G, S2-P1, S2-P2 and S1P), the second group with inverse proportions of S and Fe $e_{\text {dith }}$ (S2-PE1, S2-PE2, S2-OUT and S1-ST).

$\delta^{13} \mathrm{C}$ of organic carbon varied between $-30.0 \%$ and $-23.5 \%$ in S2-G (Figure 6) and between $-27.3 \%$ and $-21.1 \%$ in S1-P (Figure 5), and was more stable in other cores between $-23.8 \%$ and $-19.9 \%$ (Figure 6). Ratios measured in trapped particles were $-21.0 \pm 0.3 \%$. Overall, ratios in trapped particles and seabed sediment are in the same range than values from the Betsiboka estuary measured in intertidal sediments samples $(-19.8 \% \pm \pm 1.6 \%$ ), or in particles from the marine part of the estuary (between -23.6 and -16.9\%) (Ralison et al., 2008), except for sites S1-P, S2-G and S2-P2 (Figure 8).

Methane was measured on all cores but only detected on three, with concentrations up to $18.3 \mu \mathrm{M}$ at S2-P2, $14.1 \mu \mathrm{M}$ at S2-G, and $<1 \mu \mathrm{M}$ at S1-P. 


\section{DISCUSSION}

\subsection{Modern sedimentation along the Madagascar margin}

\subsubsection{Seasonal sediment transfers}

During most of the wet season, some sediment is transported offshore. The high continental fluxes favor the downslope transfer of sediments, that reach site 1 , and to a lesser extent site 2 . However, from February to May 2015, sediment fluxes at site 1 were very low despite the relative high rainfall (Figure 4). Longshore currents sometimes deflect the river plumes southwards and may reduce the sediment transport towards the continental slope, as observed on a satellite image of the $16^{\text {th }}$ March 2015 (Figure 1C), which corresponds to the period of low sediment fluxes in the slope (Figure 4). The particles recovered during the dry season at S1-P could be due to specific resuspension events, affecting sediment accumulated on the slope. The geochemical composition remains globally similar in the collected particles through the sampling period, except for $\mathrm{Mn}_{\text {dith }}$ and $\mathrm{S}$, which could evidence that some geochemical processes already altered their concentration before the resuspension happened (manganese oxides reduction and pyrite formation). This functioning scheme could be supported by lower ${ }^{210} \mathrm{~Pb}_{\mathrm{xs}}$ during the dry season (Supplementary material), as particles scavenge the ${ }^{210} \mathrm{~Pb}$ produced by the decay of ${ }^{226} \mathrm{Ra}$ in the water column, this concentration decreasing by radioactive decay once sedimented.

\subsubsection{Long-term sedimentation}

Past sedimentation rates were similar until the $1950 \mathrm{~s}$ at both sites, around $0.04-0.06 \mathrm{~cm} \mathrm{yr}^{-1}$ (Figures 5 and 6), suggesting a moderate offshore sedimentation originated from coastal rivers. A few sedimentation events (anomalies in Ti/Ca ratios) are recorded prior to 1950s at site 2, especially in S2-G, located on a steep slope of a sediment wave. This specific localization favors the preservation of sediment and prevent their erosion, with a physical protection against the currents in a slight depression. Then, sediment cores from site 2, located in different morphologies (pockmarks, 
slopes...), are subject to the same inputs but do not prevent bottom current erosion. $\mathrm{Ti} / \mathrm{Ca}$ ratio is typically used as a proxy for comparing marine and terrigenous sediment input, due to the higher content of calcium in marine sediment and higher content of titanium in terrigenous sediment (van der Lubbe et al., 2014). The question is: do these Ti/Ca anomalies recorded in the sedimentary phase came from episodic events? To start answering this question, one might look at the composition of particles collected with the sediment trap at S1-P, as the Chedza storm was sampled. Their composition do not change through time, and anomalies in the Ti/Ca ratio were not recorded with constant values around 0.047 . The tropical storm Chedza formed from the intertropical convergence zone and intensified in the Mozambique channel before quickly crossing the Island from West to East. During this storm, heavy rains occurred in central Madagascar and induced intense flooding of the Betsiboka and Mahavavy Rivers. If the Chedza storm in not one of the extreme events responsible for anomalies in $\mathrm{Ti} / \mathrm{Ca}$ ratios, can we elaborate on its contribution over the annual sedimentation? Particulate fluxes were around $2000 \mathrm{mg} \mathrm{m}^{-2} \mathrm{~d}^{-1}$ during the 3 months preceding the storm, and increased by $1 / 3$ during the event (Figure 4). The mass accumulation rate in January 2015 (cumulated on 2 sampling periods including the tropical storm Chedza) was $900 \mathrm{~g} \mathrm{~m}^{-2} \mathrm{yr}^{-1}$. If we compare this value to the MAR calculated from the ${ }^{210} \mathrm{~Pb}_{\mathrm{xs}}$ profile in $\mathrm{S} 1-\mathrm{P}$ of $1381 \mathrm{~g} \mathrm{~m}^{-2} \mathrm{yr}^{-1}$ after the 1950s, the latter is slighly higher, still in the same order of magnitude. Now if we integrate the entire sampling period for S1-ST, this accumulation rate lowers down to around $285 \mathrm{~g} \mathrm{~m}^{-2} \mathrm{yr}^{-1}$, very close to the $320 \mathrm{~g} \mathrm{~m}^{-2} \mathrm{yr}^{-1}$ estimated from the ${ }^{210} \mathrm{~Pb}_{\mathrm{xs}}$ below $16 \mathrm{~cm}$ at $\mathrm{S} 1-\mathrm{P}$ (Figure 5). The tropical storm Chedza can then be considered as an event integrated in the base sedimentation of this area, and is not extreme enough to provide the area with several centimeters of new sediment. The season 2014-2015 was a "normal" season with around 50 days of storm or cyclone activity, when exceptional seasons (1970-1971 or 1993-1994) can reach more than 90 days of activities (http://www.cycloneoi.com/pages/cyclone-ocean-indien/donnees-remarquables.html). 


\subsubsection{Episodic deposition at S1-P}

After the 1950s, the sedimentation rate at site 1 drastically increased (Figure 5), contrary to those of site 2 that remained the same than before the 1950s (Figure 6). One event, characterized by a peak in Ti/Ca ratio, was recorded at S2-P2 and probably preserved because of a lower bioturbation activity at this site (Figure 6). Several layers at S1-P (up to 6 as described in figure 5) could represent different depositional conditions. Four of these events (number 1, 3, 4, 5 - Figure 5) present a sharp increase in Ti/Ca ratios (Fontanier et al., 2018), explained by very low Ca contents. These layers, most likely from terrestrial origin, are not very clearly defined in the $\mathrm{S}$ and $\mathrm{Ti} / \mathrm{Al}$ profiles. An increase in $\mathrm{OC}$ is generally observed during these deposition events, even if the lower resolution could explain some discrepancies. As there is only evidences for these repetitive episodic events at site 1 , the simpler hypothesis would be a better connectivity between sediment sources (i.e Mahavavy outlet) and the slope depositional area. Between 1984 and 2016, images retrieved from Google earth show a difference in the coastline boundaries (Figure 9). The Mahavavy River delta and prodelta moved toward the ocean about $1 \mathrm{~km}$ and $2 \mathrm{~km}$, respectively (Figure 9). Our hypothesis is that this modern delta and prodelta progradation favors temporary connections of the river through an incised valley located around $11 \mathrm{~km}$ off the delta, to the canyon head (Figure 9 - (SHOM, 2013)). Only a few canyon systems around the world are currently able to collect the sediments and favor focused downslope turbidity flows, in such sea-level highstand mode of the present interglacial (ie. the Congo/Zaire canyon in Africa (Shepard and Emery, 1973), Monterey Canyons in America (Smith et al., 2007; Maier et al., 2018), Cap-Breton canyon (Gaudin et al., 2006; Guiastrennec-Faugas et al., 2020) and the Var canyon in Europe (Khripounoff et al, 2012)). On these narrow shelves, the canyon heads are close enough to the river outlets to be supplied with sediment by longshore drift which can directly cascade down submarine canyon heads by cooling of shelf water masses (Canals et al., 2006). It has also been evidenced that cyclones or stormy conditions can trigger very dense sediment flows, and can be responsible for significant deposits even within a disconnected canyon (Hale et al., 2012; Pope 
et al., 2017; Guiastrennec-Faugas et al., 2020). As the distance between the Outlet and the preserved incised valley is now reduced, the sediment loads, when intense enough, do not have time to be deflected by the littoral currents, and are thus mostly focused in the shelf incision and ultimately sink in the canyon head. The axial incision of the Mahavavy canyon (Figure 1) evidences modern turbidite flows that could also spread into the surrounding interfluves to reach site 1 . Most of the cyclones in this area hit the north-eastern coast and cross the island from east to west (Fitchett and Grab, 2014; Mavume, 2009). During this type of cyclones, torrential rainfall and substantial floods are generated. The high density of lavakas in central Madagascar (Cox et al., 2010) are drained by both watersheds, and this type of event could promote their erosion and lead to a very intense and fast transportation of terrestrial material. The dilution with marine particles could then be less efficient, explaining higher Ti/Ca ratios in some local deposits.

\subsection{Geochemical evidences of confined past-present methane escapes}

Sites 1 and 2 are characterized by the presence of pockmarks (Figure 1), dissolved methane measured in the upper $30 \mathrm{~cm}$ of the sedimentary column in some cores (supplementary material), as well as the manifestation of gas or fluid expulsion supported by acoustic anomalies detected in the water column (Dupré et al., 2019). Usually, when methane migrates through the sedimentary column, it is partially or totally oxidized by a consortium of anaerobic methanotrophic (ANME) and sulfate-reducing bacteria with sulfate as the terminal electron acceptor (Boetius et al., 2000; Orphan et al., 2001). This reaction, so-called anaerobic oxidation of methane (AOM) produces $\Sigma \mathrm{H}_{2} \mathrm{~S}$ and dissolved inorganic carbon (DIC), which could precipitate to form sulfur minerals (FeS, $\left.\mathrm{FeS}_{2} \ldots\right)$ and carbonates. The presence of large amount of pyrite can be related to layers in the sediment where AOM takes place (Berner, 1984; Kasten et al., 1998). Sulfate reduction can also occur through organic matter mineralization, especially in the first centimeters of sediment. Nevertheless, in the next discussion section, we tested two proxies to discriminate the sampling cores regarding to past/present methane outflux: 1) the total sulfur (mainly pyrite as revealed by additional XRD 
measurements) together with reactive iron for past activities, in addition to 2) the $\delta^{13} \mathrm{C}$ of organic matter that reflects more recent activities through the microbial biomass.

\subsubsection{S/Fe contents: indicators of the past?}

Sedimentation is a well-known controlling factor for organic matter mineralization and preservation, the latter being enhanced when sediment accumulation rates increase (Blair and Aller, 2012). As sedimentation rates increase, organic material inputs also increase and oxygen is rapidly consumed within a few millimeters of sediment (Glud, 2008). Anoxic processes, and mainly sulfate reduction, then become the major process affecting organic matter mineralization (Henrichs and Reeburgh, 1987; Pastor et al., 2011). Then, sedimentation is a controlling factor for sulfide production and iron oxides inputs, and ultimately pyritization. In deep sea sediments, where sedimentation rates are very low and organic carbon highly degraded, sulfate reduction rates never reach high enough levels to convert all the reactive iron into pyrite, resulting in the preservation of iron oxides (Raiswell and Canfield, 2012). In coastal areas, with shallower water depth and fresher organic carbon compounds, even at very low sedimentation rates and low sulfate reduction rates, sulfide production rates are still higher than the inputs of reactive iron (Canfield, 1989), represented here by the fraction of iron extracted with dithionite $\left(\mathrm{Fe}_{\text {dith }}=\right.$ amorphous Felll oxides, crystalline FellI oxides, AVS - (Kostka and Luther III, 1994)) and thus all the iron is pyritized. In the Majunga basin, at both sites 1 and 2, medium sedimentation rates $<0.07 \mathrm{~cm} \mathrm{yr}^{-1}$ and organic carbon available in relatively high concentrations $(>1 \%)$ should cause the complete pyritization of the reactive iron. Typical values for reactive iron contents in marine sediment are between 0.6 to $1.5 \%$ (Raiswell and Canfield, 2012), but here the red ferriginous/ferralitic soils from Madagascar provide the coastal area with iron rich minerals, leading to reactive iron contents close to $2-3 \%$ in surface sediments $(0-5 \mathrm{~cm})$, and still $>0.5 \%$ deeper in the sediment $(20-30 \mathrm{~cm})$ at both sites. These high values promote the local precipitation of pyrite in this area. Figure 7 shows a clear differentiation between cores. Sites inside pockmarks (S1-P, S2-P1 and S2-P2) and the site where gaseous methane in the water column have 
been detected (S2-G) are distinct from other sites, with large quantities of pyrite produced and concomitant $\mathrm{Fe}_{\text {dith }}$ consumption (Figure 7). This difference cannot be due to a difference in inputs, as cores taken at site 2 are within close proximity to each other. Even if the present methane degassing activity is not homogenous in these areas, these geochemical indicators provide a clear first overview of the impact of fluids on overall past and on-going geochemical processes.

\subsubsection{The influence of episodic extreme deposition events on pyrite formation}

As explained in the previous section, a rapid increase in accumulation rates, through episodic events for instance, carrying more organic carbon, and more iron oxi-hydroxides (up to $710 \mu \mathrm{mol} \mathrm{g}^{-1}$ ) may be responsible for an enhancement in organic matter mineralization and pyritization. The large accumulation of total sulfur (mainly authigenic pyrite) in site 1 within the first $16 \mathrm{~cm}$ (concomitant to the deposition of sediment enriched in organic carbon (Figure 5)) can only result from the precipitation of the $\Sigma \mathrm{H}_{2} \mathrm{~S}$ produced in situ during sulfate reduction. The large amount of iron in ferruginous soil exported during these events supplied the area with excess labile iron that favored pyrite formation. A sulfur budget was estimated from total sulfur measured in the sediment core, minored by a background input estimated at $0.4 \%$ from the sediment trap results (Figure 5). The measured porosity (0.78-0.92) and a dry density of $2.7 \mathrm{~g} \mathrm{~cm}^{-3}$ (standard value for mud - (Hamilton, 1976)) were used to calculate the amount of pyrite formed throughout the entire sediment core in S1-P, which would represent $3.5 \%$ of the total sulfate pool ( $28 \mathrm{mM}$ in seawater). If we only consider the sulfur peak formed between 0 and $16 \mathrm{~cm}$ depth, this would correspond to a period of approximately 65 years from ${ }^{210} \mathrm{~Pb}$ data (at the time of sampling in 2015). This would lead to an integrated rate on S1-P of sulfate reduction of around $7.5 \mathrm{mmolS} \mathrm{m}^{-2} \mathrm{~d}^{-1}$. This would be barely visible in the sulfate profile. During organoclastic sulfate reduction 2 mole of carbon are degraded per 1 mole of sulfate, and only 1 mole of carbon during AOM per 1 mole of sulfate, this would lead to an

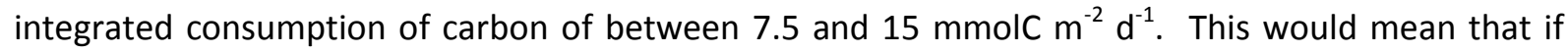
AOM was $100 \%$ responsible for the pyrite build-up, methane concentrations could have reached 
significant values $(\mathrm{mM})$ in the top layer $(0-30 \mathrm{~cm})$ and thus high fluxes. Conversely, if organoclastic sulfate reduction was the main process leading to pyrite build-up, then the deposited layers rich in OM would have enhanced sulfate reduction locally. In the end, the labile iron supplied by the events certainly enhanced the rate of pyrite formation, independently of the sulfate reduction process involved.

\subsection{3 $\delta^{13} \mathrm{C}$ of bulk organic carbon: an indicator of present methane outflux?}

At the Betsiboka River outlet, $\delta^{13} \mathrm{C}$ signatures of particulate organic carbon were $-19.8 \% \pm 1.6 \%$ in intertidal sediments samples, and ranged between -23.6 and $-16.9 \%$ in particles from the marine part of the estuary (Ralison et al., 2008). The trapped particulate matter at site 1 and most sediments fall into this range (Figure 8). Only sediment from S1-P, S2-G and S2-P2 presents more negative values (Figure 8 and supplementary material). At site 2 , all cored sites are located within a diameter of 5 kilometers and are therefore likely to receive similar settling particles with similar $\delta^{13} \mathrm{C}$ ratios. The difference in $\delta^{13} \mathrm{C}$ ratios in some cores is then not due to a change in the organic matter source, but most certainly to diagenetic processes within the sedimentary column. To decrease these ratios, up to $-30 \%$ in S2-G, another source of carbon, very depleted in ${ }^{13} \mathrm{C}$, is needed, such as methane for instance that typically exhibits negative $\delta^{13} \mathrm{C}$ ratios (Whiticar, 1999). Studies have shown the contribution of products from methanotrophs into specific organic compounds and bulk OC, leading to very negative $\delta^{13} \mathrm{C}$ ratios (Freeman et al., 1990; Hinrichs et al., 1999; Hinrichs et al., 2003; Hinrichs et al., 2000). A simple mixing model using two end-members, namely the $\delta^{13} \mathrm{C}$ of originally deposited $\mathrm{OC}$, and the $\delta^{13} \mathrm{C}$ of methane coming from below (and thus a minimum value for associated methanotrophs (feeding on this carbon source) and derived organic products), was used to estimate the potential contribution of these methanotrophs on the $\delta^{13} \mathrm{C}$ of $\mathrm{OC}$ at depth. $\delta^{13} \mathrm{C}$ of methane was measured in deeper sediment cores during the campaign PAMELA-MOZ4 (data not presented here) and a value of $-82 \%$ can be used as the first end-member. The second end-member is the $\delta^{13} \mathrm{C}$ of OC from trapped particles of $-21 \%$. Then, for the most negative values recorded for $\delta^{13} \mathrm{C}$ of $\mathrm{OC}$ of - 
$30 \%$ in $\mathrm{S} 2-\mathrm{G}$, the maximum contribution of these products into the organic matter pool can be estimated around $15 \%$ (and thus less for heavier isotopic signatures). Then, $\delta^{13} \mathrm{C}$ signatures of OC probably reflect the present abundance of methanotrophs and their by-products in sites with current high active methane escape (S2-G), past high methane escape (S1-P) and current low flux of methane (S2-P2). Compared to the two distinct groups evidenced in Figure 7 using the S/Fe indicators, S2-P1 is not considered to be impacted by methane escape using the $\delta^{13} \mathrm{C}$ signatures of OC. ANMEs have been detected on S1-P, S2-P2 and S2-G but not on S2-P1 (Odobel, 2017), which, associated with the clear difference of facies between those cores (Figure 6), underlines the high heterogeneity in this system and the complexity of choosing the right proxies to understand past and present processes.

\section{CONCLUSIONS}

This study provides a clear first insight into the sedimentation patterns along the continental slope off the Betsiboka and Mahavavy Rivers on the NW coast of Madagascar. During the wet season, particles from the two rivers are transported offshore and provide the continental slope with terrestrial material, leading to a mass accumulation rate ranging from $230-249 \mathrm{~g} \mathrm{~m}^{-2} \mathrm{yr}^{-1}$ off the Betsiboka River, to $320 \mathrm{~g} \mathrm{~m}^{-2} \mathrm{yr}^{-1}$ off the Mahavavy River, calculated from ${ }^{210} \mathrm{~Pb}^{\mathrm{xs}}$ in surficial sediment cores. The sediment trap off the Mahavavy River on the slope falls well within this range with $285 \mathrm{~g}$ $\mathrm{m}^{-2} \mathrm{yr}^{-1}$ during 2014-2015. Yet since the 1950s, a higher mass accumulation rate of $1381 \mathrm{~g} \mathrm{~m}^{-2} \mathrm{yr}^{-1}$ is recorded in sediment cores off the Mahavavy River. This increase is probably due to temporal reconnection of the river with the head of the canyon during extreme events, as supported by a significant progradation of the delta and prodelta of around 1 and $2 \mathrm{~km}$ respectively, and a well incised canyon reflecting recent turbidite activity. We suspect that these pulsed deposits, rich in organic carbon and iron oxides, enhance some geochemical processes and ultimately the pyritization process. More globally, the amount of pyrite on the continental slope seems to be driven by methane upward migration, locally enhancing sulfate reduction and thus the amount of free sulfide 
produced. This influence is also supported in the $\delta^{13} \mathrm{C}$ of bulk organic carbon, with a significant contribution of methanotrophs to the organic carbon pool.

\section{Acknowledgements}

We would like to thank the captain and crew members of the R/V L'Atalante and RV Pourquoi pas?, the chiefs scientist (Karine Olu, Stéphanie Dupré, Gwenael Jouet and Eric Deville) and all scientists who took part in PAMELA-MOZ1 and PAMELA-MOZ4 cruises. Thanks also go to Céline Liorzou at the PSO/IUEM (France) for technical support with the ICP-AES, Philippe Noël and Jean-Pierre Brulport from Ifremer for technical help with mooring and sampling, Alexis Khripounoff from Ifremer for current data, Bernard Dennielou, Angélique Roubi and Jérémie Gouriou from Ifremer for semiquantitative XRF, Alison Chalm from Ifremer for english editing and Julie Tourolle from Ifremer for help with the SIG. We would like to thank the two anonymous reviewers for their constructive comments that helped improve this manuscript. This study was completed as part of the PAMELA project ("Passive Margin Exploration Laboratories") funded by TOTAL and Ifremer. The authors acknowledge the use of imagery from the NASA Worldview application (https://worldview.earthdata.nasa.gov), part of the NASA Earth Observing System Data and Information System (EOSDIS). 
Balslev-Clausen, D., Dahl, T. W., Saad, N., and Rosing, M. T., 2013, Precise and accurate delta C-13 analysis of rock samples using Flash Combustion-Cavity Ring Down Laser Spectroscopy: Journal of Analytical Atomic Spectrometry, v. 28, no. 4, p. 516-523.

Battistini, R., 1972, L'hypothèse de l'absence de hauts stationnements marins quaternaires : Essai d'application à Madagascar et au sud-ouest de l'océan Indien: Quaternaire, p. 75-81.

Bauer, J. E., Cai, W.-J., Raymond, P. A., Bianchi, T. S., Hopkinson, C. S., and Regnier, P. A. G., 2013, The changing carbon cycle of the coastal ocean: Nature, v. 504, no. 7478, p. 61-70.

Berner, R. A., 1984, Sedimentary pyrite formation: An update: Geochimica et Cosmochimica Acta, v. 48 , no. 4, p. 605-615.

Berthois, L., and Crosnier, A., 1966, Etude dynamique de la sédimentation au large de l'estuaire de la Betsiboka: cah. O.R.S.T.O.M., sér. Océanogr., v. IV, no. 2.

Blair, N. E., and Aller, R. C., 2012, The Fate of Terrestrial Organic Carbon in the Marine Environment: Annual Review of Marine Science, v. 4, no. 1, p. 401-423.

Boetius, A., Ravenschlag, K., Schubert, C. J., Rickert, D., Widdel, F., Gieseke, A., Amann, R., Jorgensen, B. B., Witte, U., and Pfannkuche, O., 2000, A marine microbial consortium apparently mediating anaerobic oxidation of methane: Nature, v. 407, no. 6804, p. 623-626.

Burdige, D. J., 2005, Burial of terrestrial organic matter in marine sediments: A re-assessment: Global Biogeochemical cycles, v. 19, p. 1-7.

Canals, M., Puig, P., de Madron, X. D., Heussner, S., Palanques, A., and Fabres, J., 2006, Flushing submarine canyons: Nature, v. 444, no. 7117, p. 354-357.

Canfield, D. E., 1989, Sulfate reduction and oxic respiration in marine sediments: Implications for organic carbon preservation in euxinic environments.: deep Sea Research Part, v. 36, p. 121138.

Chaperon, P., Daloux, J., and Ferry, L., 1993, Fleuves et Rivières de Madagascar, Ministère de la Recherche Scientifique, Ministère du Transport et de la Météorologie.

Collins, C., Hermes, J. C., and Reason, C. J. C., 2014, Mesoscale activity in the Comoros basin from satellite altimetry and a high-resolution ocean circulation model. Journal of Geophysical Research: Oceans, v. 119, no. 8, p. 4745-4760.

Collins, C., Hermes, J. C., Roman, R. E., and Reason, C. J. C., 2016, First dedicated hydrographic survey of the C omoros B asin. Journal of Geophysical Research: Oceans, v. 121, no. 2, p. 1291-1305.

Cox, R., Zentner, D. B., Rakotondrazafy, A. F. M., and Rasoazanamparany, C. F., 2010, Shakedown in Madagascar: Occurrence of lavakas (erosional gullies) associated with seismic activity: Geology, v. 38, no. 2, p. 179-182.

Dupré, S., Battani, A., Deville, E., Scalabrin, C., Olu, K., Poort, J., Bermell, S., Dupont, P., Gaillot, A., Guérin, C., Pierre, D., Ogor, A., Théréau, E., Thomas, Y., Jouët, G., and Jorry, S., 2019, Focused fluid flows and seeps offshore southern Majunga Basin (NW Madagascar), AGU Fall Meeting: San Francisco, USA, p. 515706.

Edgar, K. M., Anagnostou, E., Pearson, P. N., and Foster, G. L., 2015, Assessing the impact of diagenesis on delta B-11, delta C-13, delta $\mathrm{O}-18, \mathrm{Sr} / \mathrm{Ca}$ and $\mathrm{B} / \mathrm{Ca}$ values in fossil planktic foraminiferal calcite: Geochimica Et Cosmochimica Acta, v. 166, p. 189-209.

Fitchett, J. M., and Grab, S. W., 2014, A 66-year tropical cyclone record for south-east Africa: temporal trends in a global context: International Journal of Climatology, v. 34, no. 13, p. 3604-3615.

Fontanier, C., Mamo, B., Toucanne, S., Bayon, G., Schmidt, S., Deflandre, B., Dennielou, B., Jouet, G., Garnier, E., Sakai, S., Lamas, R. M., Duros, P., Toyofuku, T., Salé, A., Belleney, D., Bichon, S., Boissier, A., Chéron, S., Pitel, M., Roubi, A., Rovere, M., Grémare, A., Dupré, S., and Jorry, S. J., 2018, Are deep-sea ecosystems surrounding Madagascar threatened by land-use or climate change?: Deep Sea Research Part I: Oceanographic Research Papers, v. 131, p. 93100 . 
Freeman, K. H., Hayes, J. M., Trendel, J.-M., and Albrecht, P., 1990, Evidence from carbon isotope measurements for diverse origins of sedimentary hydrocarbons: Nature, v. 343, p. 254.

Glud, R. N., 2008, Oxygen dynamics of marine sediments: Marine Biology Research, v. 4, p. 243-289.

Hale, R. P., Nittrouer, C. A., Liu, J. T., Keil, R. G., and Ogston, A. S., 2012, Effects of a major typhoon on sediment accumulation in SW Taiwan: Marine Geology, v. 326, p. 116-130.

Hamilton, E. L., 1976, VARIATIONS OF DENSITY AND POROSITY WITH DEPTH IN DEEP-SEA SEDIMENTS: Journal of Sedimentary Petrology, v. 46, no. 2, p. 280-300.

Harper, G. J., Steininger, M. K., Tucker, C. J., Juhn, D., and Hawkins, F., 2007, Fifty years of deforestation and forest fragmentation in Madagascar: ENVIRONMENTAL CONSERVATION, $v$. 34, no. 4, p. 325-333.

Henrichs, S. M., and Reeburgh, W. S., 1987, Anaerobic mineralization of marine sediment organic matter: rates and the role of anaerobic processes in the oceanic carbon economy.: Geomicrobiology, v. 5, p. 191-236.

Hinrichs, K.-U., Hayes, J. M., Sylva, S. P., Brewer, P. G., and DeLong, E. F., 1999, Methane-consuming archaebacteria in marine sediments: Nature, v. 398, p. 802

Hinrichs, K. U., Hmelo, L. R., and Sylva, S. P., 2003, Molecular fossil record of elevated methane levels in late pleistocene coastal waters: Science, v. 299, no. 5610, p. 1214-1217.

Hinrichs, K. U., Summons, R. E., Orphan, V., Sylva, S. P., and Hayes, J. M., 2000, Molecular and isotopic analysis of anaerobic methane-oxidizing communities in marine sediments: Organic Geochemistry, v. 31, no. 12, p. 1685-1701.

Jouet, G., and Deville, E., 2015, PAMELA-MOZ04 cruise, RV Pourquoi Pas?: http://dx.doi.org/10.17600/15000700.

Kasten, S., Freudenthal, T., Gingele, F. X., and Schulz, H. D., 1998, Simultaneous formation of iron-rich layers at different redox boundaries in sediments of the Amazon deep-sea fan: Geochimica et Cosmochimica Acta, v. 62, no. 13, p. 2253-2264.

Klein, J., 2002, Deforestation in the Madagascar Highlands - Established 'truth' and scientific uncertainty: GeoJournal, v. 56, no. 3, p. 191-199.

Kostka, J. E., and Luther III, G. W., 1994, Partitioning and speciation of solid phase iron in saltmarsh sediments: Geochimica et Cosmochimica Acta, v. 58, p. 1701-1710.

Larrasoana, J. C., Roberts, A. P., Gracia, E., Musgrave, R. J., Pinero, E., Vega, M., and Martinez-Ruiz, F., 2009, Magnetite Dissolution and Authigenic Magnetic Iron Sulphide Formation in Gas Hydrate- bearing Marine Sediments: Implications for Paleo- and Environmental Magnetic Studies, AGU Spring Meeting Abstracts, Volume 2009.

Mavume, A. F., Rydberg, K., Rouault, M., Lutjeharms, J.R.E, 2009, Climatology and landfall of tropical cyclones in the South-West Indian Ocean: West Indian J. Mar. Sci, v. 8, no. 1, p. 15-36.

M'arthur, J. M., Tyson, R. V., Thomson, J., and Mattey, D., 1992, Early diagenesis of marine organic matter: Alteration of the carbon isotopic composition: Marine Geology, v. 105, no. 1, p. 5161.

Odobel, C., 2017, Dynamique spatiale et temporelle des communautés Archaea et Bacteria dans les sédiments marins profonds du canal du MozambiquePhD thesis].

Olu, K., 2014, PAMELA-MOZ01 cruise, RV L'Atalante: http://dx.doi.org/10.17600/14001000.

Orphan, V. J., Hinrichs, K. U., Ussler, W., Paull, C. K., Taylor, L. T., Sylva, S. P., Hayes, J. M., and Delong, E. F., 2001, Comparative analysis of methane-oxidizing archaea and sulfate-reducing bacteria in anoxic marine sediments: Applied and Environmental Microbiology, v. 67, no. 4, p. 19221934.

Pastor, L., Cathalot, C., Deflandre, B., Viollier, E., Soetaert, K., Meysman, F. J. R., Ulses, C., Metzger, E., and Rabouille, C., 2011, Modeling biogeochemical processes in sediments from the Rhône River prodelta area (NW Mediterranean Sea): Biogeosciences, v. 8, no. 5, p. 1351-1366.

Pope, E. L., Talling, P. J., Carter, L., Clare, M. A., and Hunt, J. E., 2017, Damaging sediment density flows triggered by tropical cyclones: Earth and Planetary Science Letters, v. 458, p. 161-169. 
Pripp, T., Gammelsrød, T., \& Krakstad, J. O., 2014, Physical influence on biological production along the western shelf of Madagascar. Deep Sea Research Part II: Topical Studies in Oceanography, v. 100, p. 174-183.

Raiswell, R., and Canfield, D. E., 2012, The iron biogeochemical cycle past and present: Geochemical Perspectives, v. 1, no. 1, p. 1-220.

Ralison, O. H., Borges, A. V., Dehairs, F., Middelburg, J. J., and Bouillon, S., 2008, Carbon biogeochemistry of the Betsiboka estuary (north-western Madagascar): Organic Geochemistry, v. 39, no. 12, p. 1649-1658.

Ramifehiarivo, N., Brossard, M., Grinand, C., Andriamananjara, A., Razafimbelo, T., Rasolohery, A., Razafimahatratra, H., Seyler, F., Ranaivoson, N., Rabenarivo, M., Albrecht, A., Razafindrabe, F., and Razakamanarivo, H., 2017, Mapping soil organic carbon on a national scale: Towards an improved and updated map of Madagascar: Geoderma Regional, v. 9, p. 29-38.

Randrianarijaona, P., 1983, The erosion of Madagascar: Ambio, v. 12, p. 308-311.

Roberts, G. G., Paul, J. D., White, N., and Winterbourne, J., 2012, Temporal and spatial evolution of dynamic support from river profiles: A framework for Madagascar: Geochemistry, Geophysics, Geosystems, v. 13, no. 4.

Salomon, J.-N., 2009, L'accrétion littorale sur la côte Ouest de Madagascar: Physio-Géo, v. 3, no. 1, p. 35-59.

Sarradin, P. M., and Caprais, J. C., 1996, Analysis of dissolved gases by headspace sampling gas chromatography with column and detector switching. Preliminary results: Analytical Communications, v. 33, no. 10, p. 371-373.

Schmidt, S., Howa, H., Mouret, A., Lombard, F., Anschutz, P., and Labeyrie, L., 2009, Particle fluxes and recent sediment accumulation on the Aquitanian margin of Bay of Biscay: Continental Shelf Research, v. 29, no. 8, p. 1044-1052.

Shepard, F.P., Emery, K.O., 1973. Congo Submarine Canyon and Fan Valley. AAPG Bulletin 57 (9), 1679-1691.

SHOM, 2013, Carte marine 7486 - Canal du Mozambique partie nord.

Tari, G., Coterill, K., Molnar, J., Valasek, D., Walters, G. and Alvarez, Y., 2004. Salt Tectonics and Sedimentation in the Offshore Majunga Basin, Madagascar. Transactions GCSSEPM Foundation. 24. 614-628. 10.5724/gcs.04.24.0614.

van der Lubbe, J. J. L., Tjallingii, R., Prins, M. A., Brummer, G.-J. A., Jung, S. J. A., Kroon, D., and Schneider, R. R., 2014, Sedimentation patterns off the Zambezi River over the last 20,000years: Marine Geology, v. 355, no. Supplement C, p. 189-201.

Whiticar, M. J., 1999, Carbon and hydrogen isotope systematics of bacterial formation and oxidation of methane: Chemical Geology, v. 161, no. 1-3, p. 291-314. 
Table 1: Position of sampling. MLP stands for mooring and MTB for sediment core.

\begin{tabular}{|c|c|c|c|c|c|c|c|c|}
\hline Site & Position & $\begin{array}{l}\text { Latitude } \\
\text { (S) }\end{array}$ & $\begin{array}{l}\text { Longitude } \\
\text { (E) }\end{array}$ & $\begin{array}{c}\text { Depth } \\
(\mathrm{m})\end{array}$ & Cruise label & Designation & $\begin{array}{c}\text { Date } \\
\text { (dd/mm/yy) }\end{array}$ & $\begin{array}{c}\text { Depth } \\
(\mathrm{m})\end{array}$ \\
\hline \multirow{2}{*}{ Site 1} & $\begin{array}{c}\text { above the } \\
\text { pockmark } \\
\text { (Sediment Trap) }\end{array}$ & $15^{\circ} 31.160$ & $45^{\circ} 42.943$ & 781 & MLP1 & S1-ST & $\begin{array}{c}26 / 10 / 14- \\
15 / 11 / 15\end{array}$ & 781 \\
\hline & $\begin{array}{l}\text { inside the } \\
\text { Pockmark }\end{array}$ & 1531.148 & 4542.931 & 789 & $\begin{array}{l}\text { MOZ1- } \\
\text { MTB6/7 }\end{array}$ & S1-P & $07 / 10 / 2014$ & 789 \\
\hline \multirow{6}{*}{ Site 2} & \multirow{2}{*}{$\begin{array}{l}\text { inside the } \\
\text { Pockmark }\end{array}$} & 1521.815 & 4557.648 & 740 & $\begin{array}{l}\text { MOZ1- } \\
\text { MTB8/9 }\end{array}$ & S2-P1 & 09/10/2014 & 740 \\
\hline & & 1521.812 & 4557.628 & 735 & $\begin{array}{l}\text { MOZ4- } \\
\text { MTB1 }\end{array}$ & $\mathrm{S} 2-\mathrm{P} 2$ & $13 / 11 / 2015$ & 735 \\
\hline & at the Pockmark & 1521.695 & 4557.388 & 757 & $\begin{array}{l}\text { MOZ1- } \\
\text { MTB3 }\end{array}$ & S2-PE1 & $06 / 10 / 2014$ & 757 \\
\hline & Edge & 1521.685 & 4557.378 & 754 & $\begin{array}{l}\text { MOZ4- } \\
\text { MTB2 }\end{array}$ & S2-PE2 & $14 / 11 / 2015$ & 754 \\
\hline & $\begin{array}{c}\text { OUTside the } \\
\text { pockmarks area }\end{array}$ & 1522.047 & 4559.210 & 529 & $\begin{array}{l}\text { MOZ1- } \\
\text { MTB1/2 }\end{array}$ & S2-OUT & $04 / 10 / 2014$ & 529 \\
\hline & $\begin{array}{c}\text { On observed Gas } \\
\text { escape }\end{array}$ & 1522.230 & 4557.110 & 762 & $\begin{array}{l}\text { MOZ4- } \\
\text { MTB3/4 }\end{array}$ & S2-G & $14 / 11 / 2015$ & 762 \\
\hline
\end{tabular}




\section{FIGURE CAPTIONS}

Figure 1: (A) The NW Madagascar margin and the Mahavavy and Betsiboka watersheds. The two main sites (S1, S2) are indicated by a star. (B) Detailed bathymetry of the sampled area and location of the sampling sites (C) Satellite image (MODIS/Aqua corrected reflectance) of 16 March 2015, obtained from the NASA Worldview application, showing how river plumes are deflected towards the north by alongshore currents and sediment in suspension is carried from the northern part towards the south by longshore currents.

Figure 2: (A) Temperature and speed time series at $30 \mathrm{~m}$ above the seafloor at S1. The light blue curves represent the raw data and the dark blue lines averaged values every $12 \mathrm{~h}$. (B) Rose diagram of current direction and speed at $30 \mathrm{~m}$ above the seafloor at S1.

Figure 3: Spectra of kinetic energy based current velocity (A) and temperature (B) at $S 1$ (blue line) and 98\% confidence level (red lines). M2 is the semi-diurnal tide (12.42 h) and M4 is the quatridiurnal tidal constituent (6.21 h).

Figure 4: Geochemical data from suspended particulate matter in Site 1 collected with a sediment trap positioned $10 \mathrm{~m}$ above the sediment surface. TMF stands for total mass flux. The pink shaded bar represents the interval in which the tropical storm Chedza happened.

Figure 5 Geochemical data and photograph of sediment core from S1-P. SR: Sediment accumulation Rates. OC: Organic Carbon content. The dashed line represents the limit around 1950s. The top part of the core has been divided in 6 layers which could represent different sedimentation events

Figure 6: Geochemical data and photographs of sediment cores from Site 2. SR stands for the Sediment accumulation Rates. The dashed line represents the limit around 1950s. The orange and gray shaded bars represents the main visual sediment layer at the top of each core

Figure 7: Ternary plot of organic carbon (OC), sulfur content $(S)$ and crystalline iron oxi-hydroxides $\left(F e_{\text {dith }}\right)$ for multitube cores (MTB) and particles from the sediment trap

Figure 8: Summary of $\delta^{13} \mathrm{C}$ values on particulate organic matter from the moored sediment trap and the sediment cores. Data are shown as boxplots; lines represents the median and $75 \%$ interquartile ranges, error bars show the $90 \%$ intervals, and extremes are shown as black circles. For comparison, the typical range of $\delta^{13} \mathrm{C}$ values for $\mathrm{C} 3$ and $\mathrm{C} 4$ derived organic 
matter are indicated as between dotted lines, and the range of $\delta^{13} \mathrm{C}$ values of particulate organic carbon and intertidal sediments (75\% interquartile ranges) (from (Ralison et al., 2008) as a hatched area

Figure 9: Satellite image of the Mahavavy delta and prodelta in 2016. White dashed lines represent the location of the delta and prodelta in 1984. The red dashed line stands for particles export through the incised valley to the head of the canyon during extreme events. Images from google maps 


\section{Conflict of interest}

The authors declare that they have no conflict of interest. 
Highlights

- The NW continental slope of Madagascar presents moderate sediment accumulation rates, with sediment transport mainly during the wet season

- Recent episodic sedimentation events are due to temporary reconnection of the Mahavavy River with its canyon head during extreme events

- These episodic events carry sediment rich in organic carbon and iron oxides, which influence geochemical processes in the sedimentary column

- The large inputs of iron oxides in this area enhance pyritization efficiency

- Past and present methane outputs influence geochemical signatures in the sediment (sulfur minerals and $\delta^{13} \mathrm{C}$ of bulk organic carbon) 


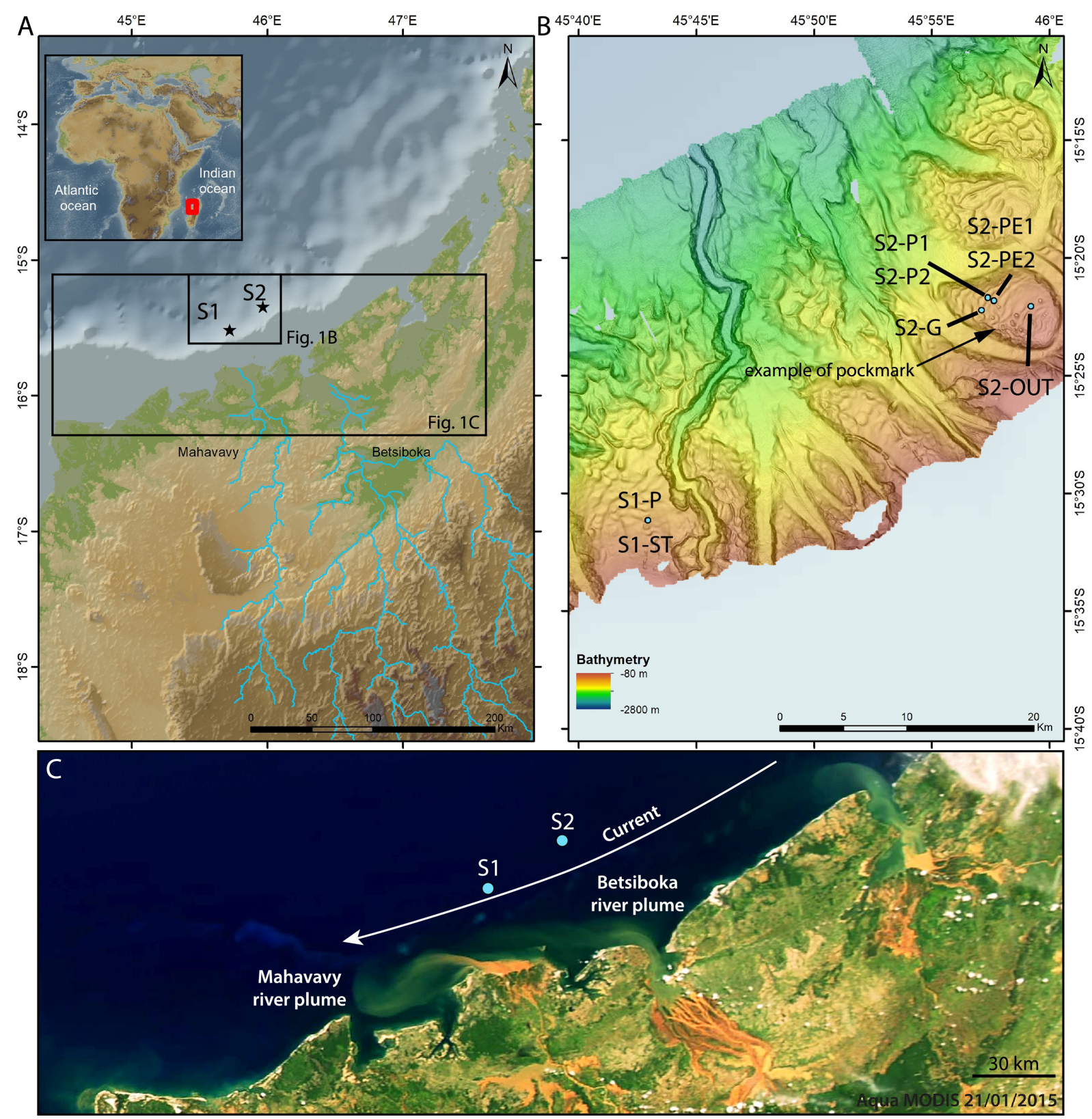

Figure 1 


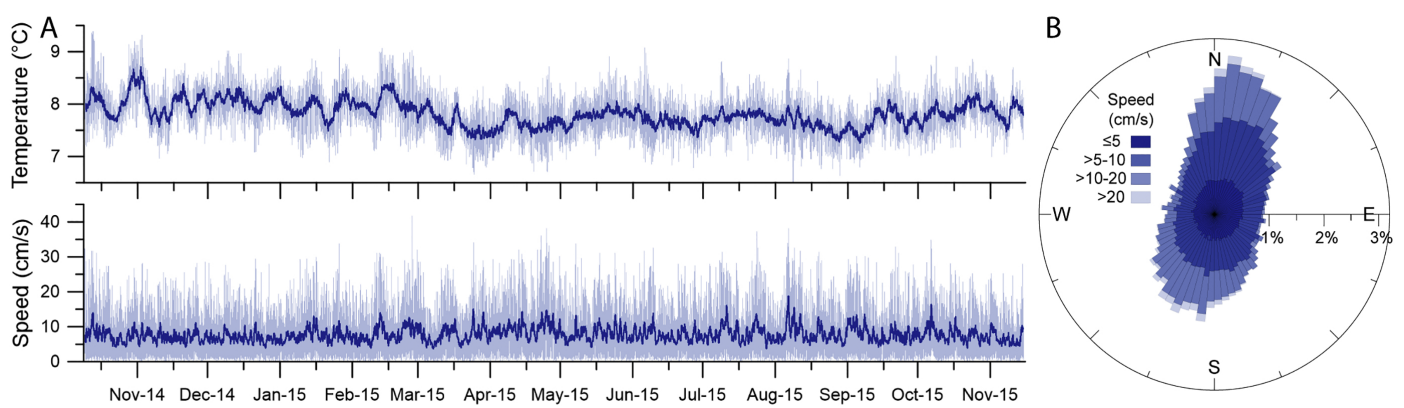

Figure 2 

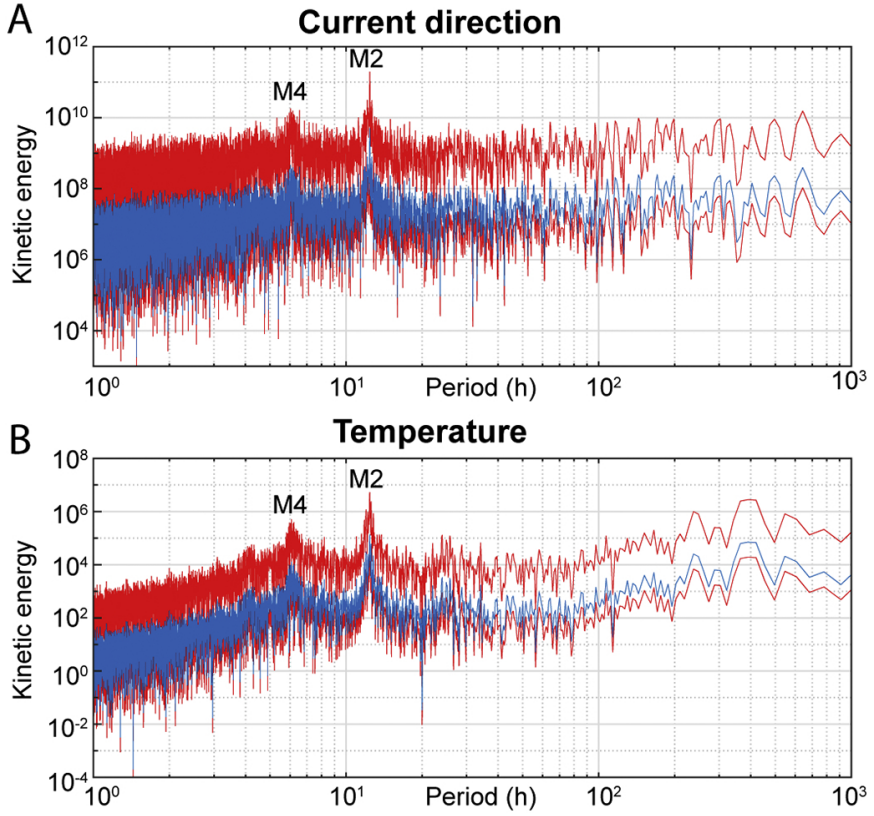

Figure 3 

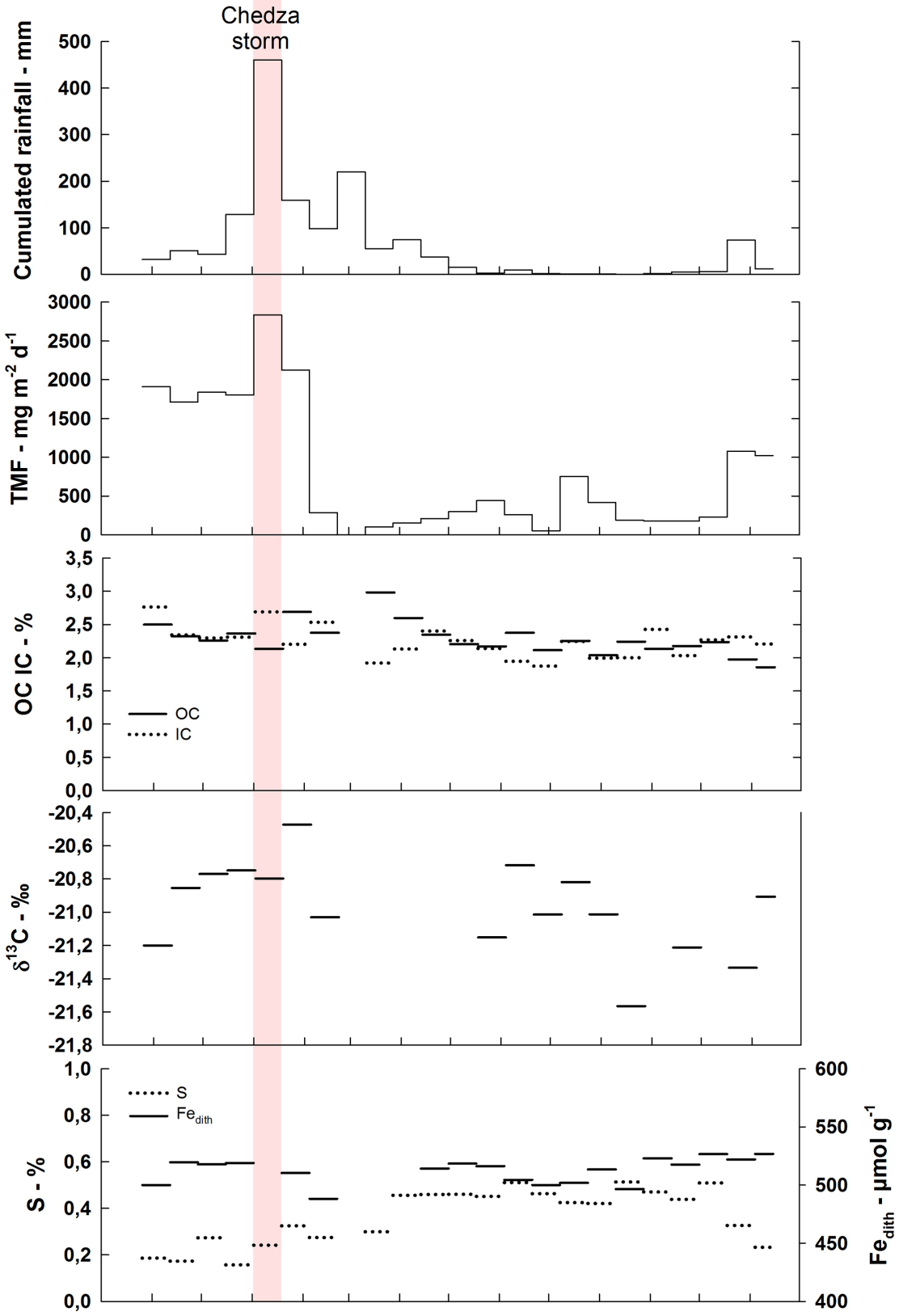

Oct. Nov. Dec. Jan. Feb. Mar. Apr. May June Jul. Aug. Sept. Oct. Nov. Dec

Figure 4 


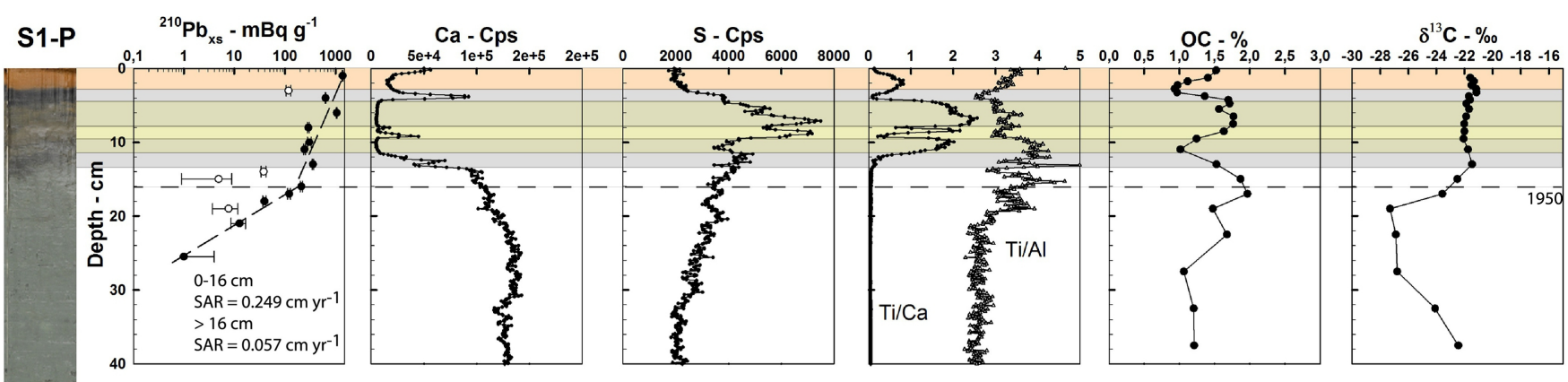

Figure 5 

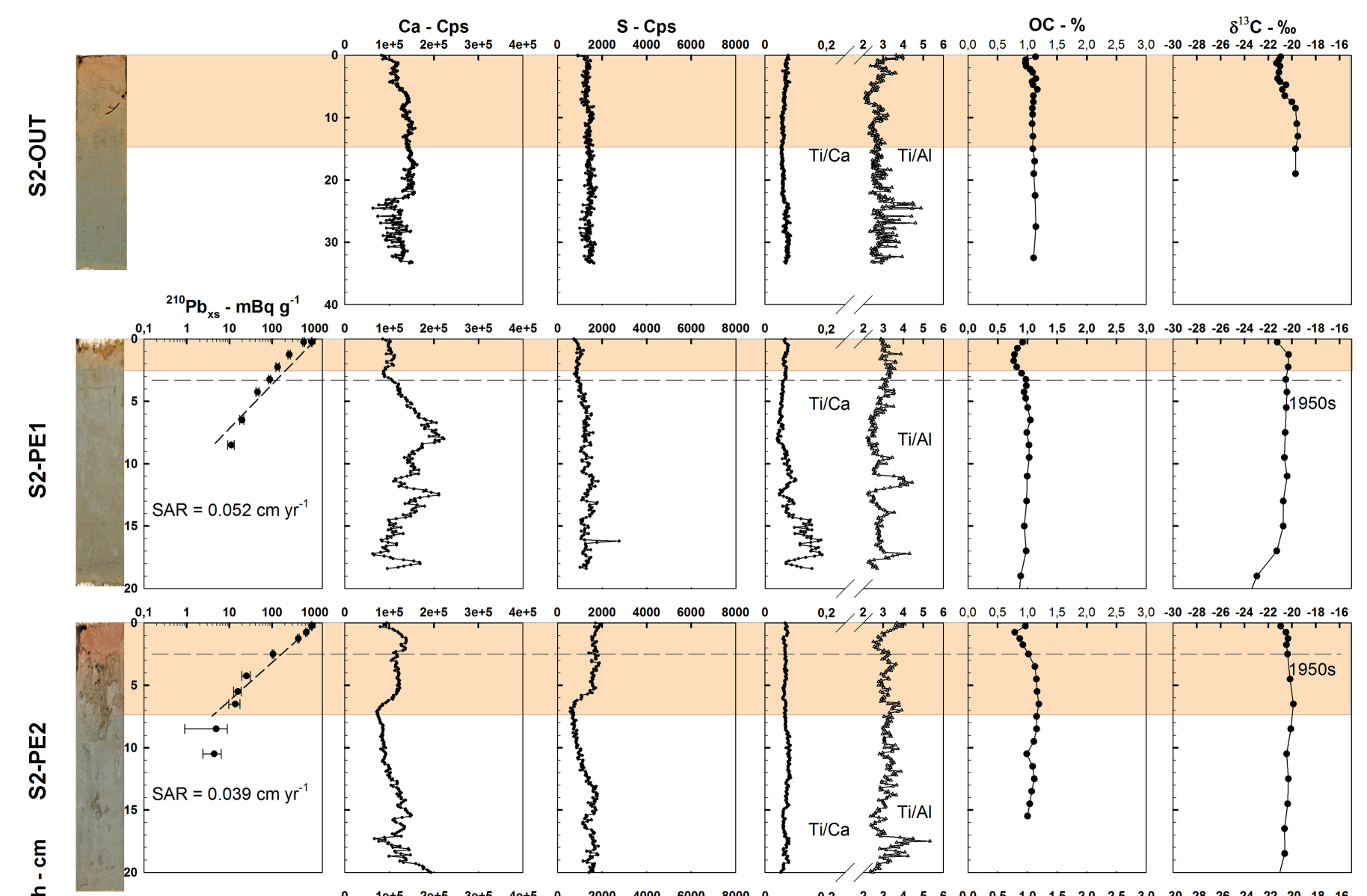

.
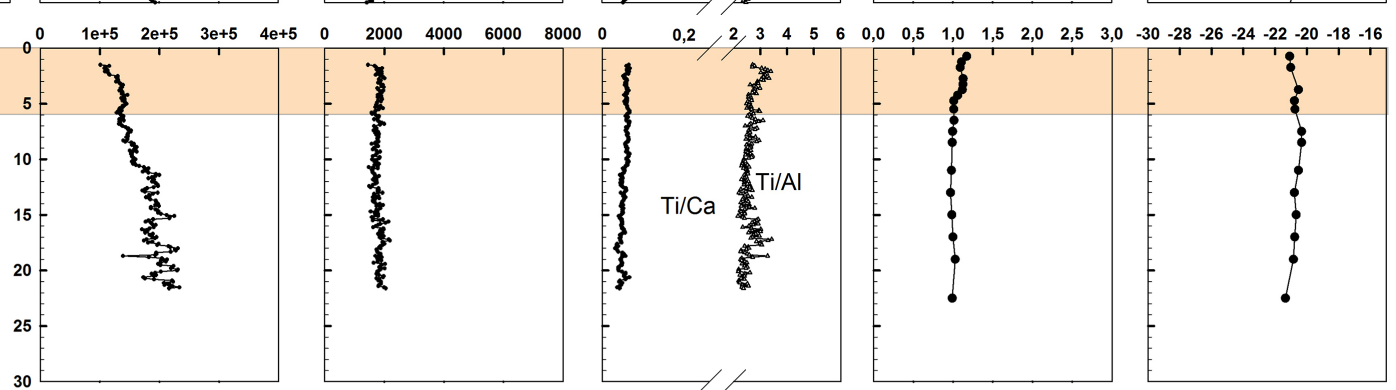

กิ
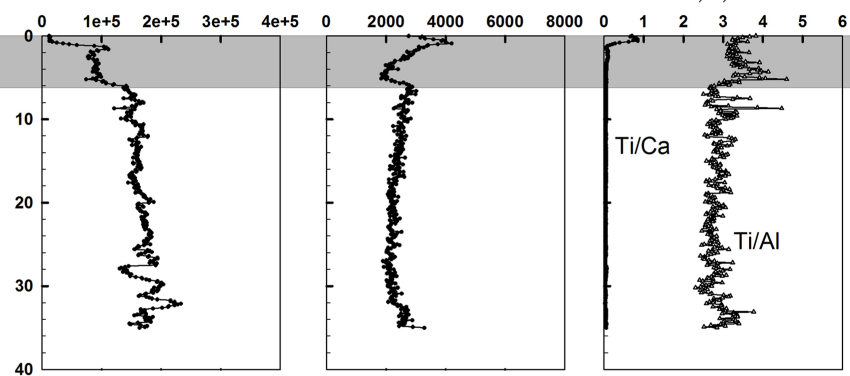

$\begin{array}{llllllllllllllll}6,0 & 0,5 & 1,0 & 1,5 & 2,0 & 2,5 & 3,0 & \mathbf{- 3 0} & \mathbf{2} 8 & \mathbf{2} 6 & \mathbf{2} 24 & \mathbf{2 2} & \mathbf{- 2 0} & \mathbf{- 1 8} & \mathbf{- 1 6}\end{array}$

${ }^{210} \mathrm{~Pb}_{\mathrm{xs}}-\mathrm{mBq} \mathrm{g}^{-1}$
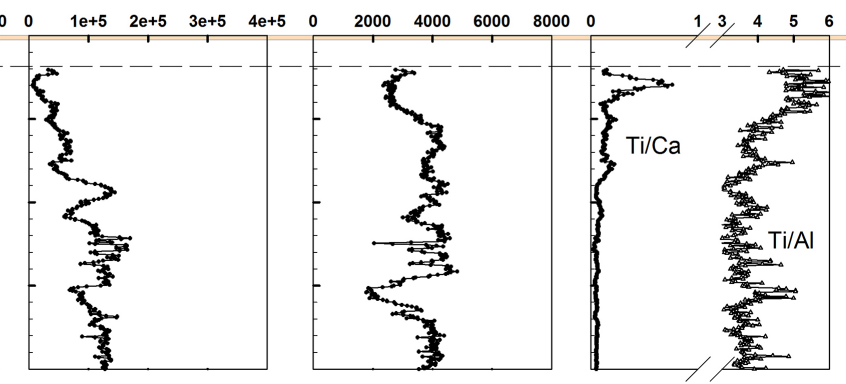

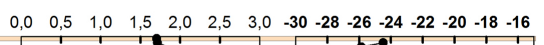
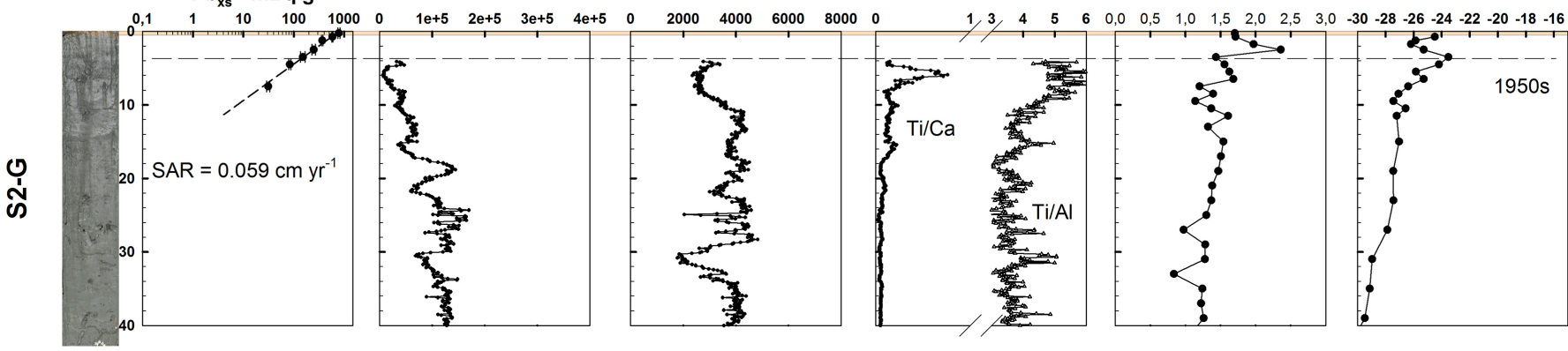


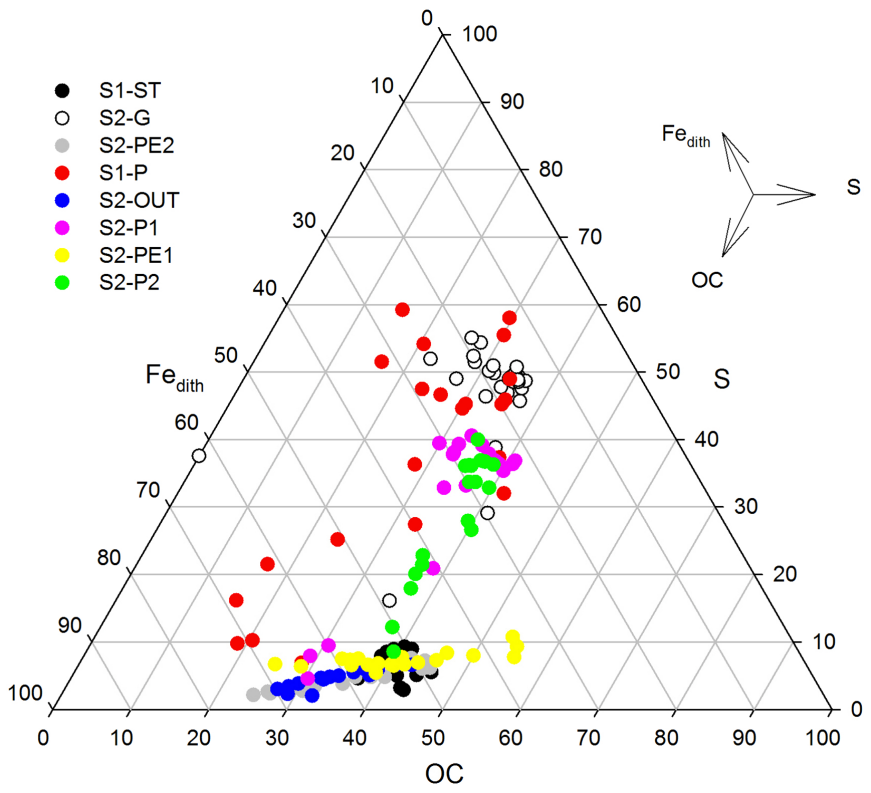

Figure 7 


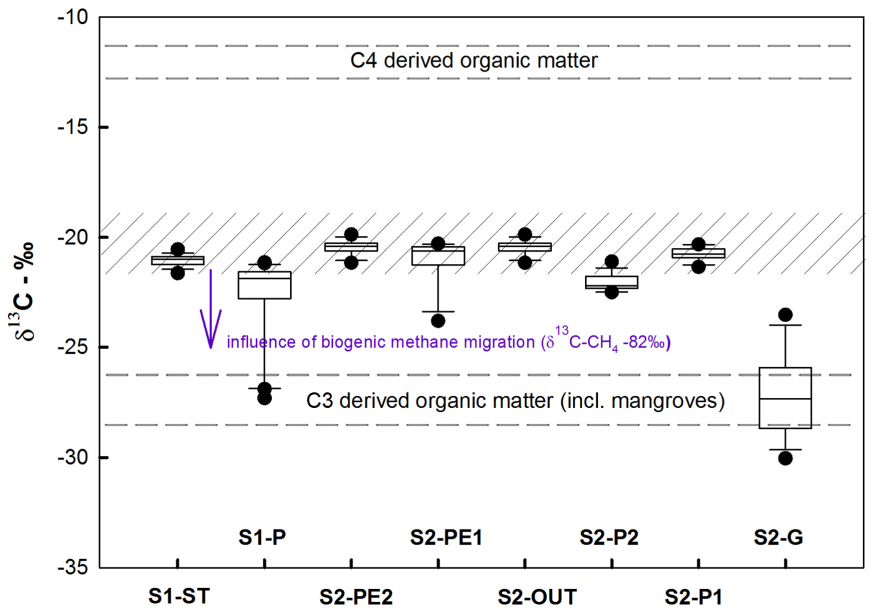

Figure 8 


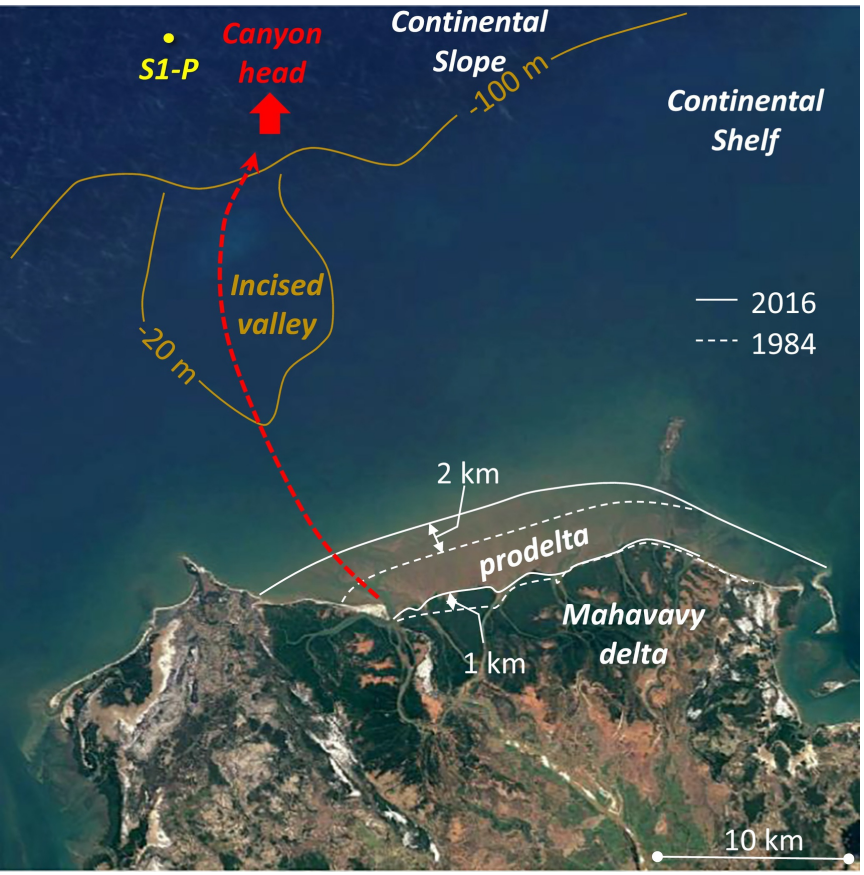

Figure 9 